Please do not remove this page

RMIT

UNIVERSITY

\title{
Money management and control in the Indian joint family across generation
}

Singh, Supriya; Bhandari, Mala

https://researchrepository.rmit.edu.au/esploro/outputs/9921858021501341/filesAndLinks?institution=61RMIT_INST\&index=null

Singh, S., \& Bhandari, M. (2012). Money management and control in the Indian joint family across generation. The Sociological Review, 60(1), 46-67. https://doi.org/10.1111/j.1467-954X.2011.02047.x Document Version: Submitted Version

Published Version: https://doi.org/10.1111/j.1467-954X.2011.02047.x

Repository homepage: https://researchrepository.rmit.edu.au

(c) 2012 The Authors. The Sociological Review (c) 2012 The Editorial Board of The Sociological Review

Downloaded On 2023/04/26 22:46:03 +1000 


\title{
Money management and control in the Indian joint family across generations
}

\author{
By Supriya Singh* and Mala Bhandari
}

* Lead author

Supriya Singh

Mala Bhandari

RMIT University

Social and Development Research and

GPO Box 2476, Action Group,

Melbourne 3001,

L - 16, Sec. - 25, Noida (U.P.),

Australia

India

Supriya.singh@rmit.edu.au

mail@sadrag.org 


\section{Abstract}

Studies of money management and control will have more cross-cultural relevance if the family context of money across generations is taken into account. The study of money management and control in middle-income nuclear and joint family households in urban India illustrates the importance of examining money flows within the wider family context because there is a two-way flow of money beyond the married couple between parents and adult children, siblings and other members of the extended family. In the three or four generational joint family, control and management at the household level is not necessarily duplicated for the constituent couples. We draw on open-ended interviews of 40 persons from 27 urban middle-income households in North India, between November 2007 and January 2008, to show that the male control of money is the dominant pattern. This pattern is linked to the ideology of male dominance that is found among the middle, lower middle and struggling households, particularly in nonmetropolitan households. The upper middle class households predominantly in metropolitan households show a pattern of joint or independent control. The focus is on the couple’s money decisions within the context of the wider family.

Keywords: Patrilineal joint family; money management and control; family money; gender; generation 


\section{Money management and control in the Indian joint family across generations}

\section{Introduction}

Studies of money management and control would have more cross-cultural relevance if they considered the family context of money across generations. Much previous research on money management has focused on the married couple and at one point in time. However, for a fuller understanding of the variations of money management and control in diverse family structures and practices, we need to look at the wider family and take a cross-generational perspective. In some countries in the West, men and women use money as a means by which they 'construct themselves as a couple' (Nyman and Reinikainen, 2007). In many countries in the Asia-Pacific and Africa, it is essential to go beyond the couple in the household to understand the allocation of household money, for money can be one of the ways people present themselves as a family.

We illustrate the usefulness of this broader family approach to money through a focus on urban, middle-income, Indian patrilineal nuclear and joint family households in North India. Unlike money in middle-income Anglo-Celtic families in Australia and the United Kingdom, there is a two-way flow of money and information between parents, children and other kin. The generational perspective is important in extended family households for it distinguishes between money management and control at the level of the component couples and the household. We argue that a focus on generation and gender in money management and control will better address the complexities of 
money and power in transnational families as well as diverse versions of the extended family across cultures.

\section{Money management and control in the literature}

The current typology is built around the distinction between money management and control. Money management is widely interpreted as organising money in the household on a day to day basis, whereas money control is linked to the power to make major financial decisions or prevent discussion about these decisions (Pahl, 1989 , Vogler, 1998 , Vogler and Pahl, 1993 , Vogler et al., 2008 , Lukes, 1974). The initial thrust of the study of money management and control, particularly in the United Kingdom, was to go beyond the household as a 'black box' to study the allocation of money between the marital couple. Jan Pahl writing in 1989 distinguished between the whole wage system where the husband gave most of his wages to his wife to manage; and the housekeeping allowance system, where the man gave his wife an agreed amount to cover household expenses. Sometimes it included a margin for personal spending money. About half the couples used pooled systems, sharing overall management and control (Pahl, 1989). This collective approach to money differed from the more individualistic partial pooling where some money was shared and the rest kept separate and independent management and control (Vogler et al., 2008 , Pahl, 1989 , Vogler and Pahl, 1993).

More recently the focus has moved to charting the more individualistic management and control of money in intimate relationships, particularly among younger and more affluent couples (Pahl, 2008). Cohabiting couples prefer separate money as a reflection of equality even if it does not make for equity in relationships (Vogler et al., 2008 , Vogler, 2005 , Elizabeth, 2001 , Singh and Lindsay, 1996). This 
tension between equality and equity was seen particularly among childless and postmarital cohabiting unions (VOGLER, 2009). This conflict between equality and equity is also found in Sweden where couple relationships present themselves as equal despite inequalities in male and female earning power (Nyman, 2003 , Nyman and Reinikainen, 2007). Part of this tension is because of the perceived ownership of money (BURGOYNE and SONNENBERG, 2009). Remarried couples also preferred a more individualised approach to money as they addressed financial obligations arising from previous relationships (Pahl, 2008 , Vogler et al., 2008 , Burgoyne, 2004 , Lown and Dolan, 1988 , Burgoyne and Morison, 1997).

There is some discussion that the individualisation thesis paints too 'monochrome' a picture as it does not capture money relationships in transnational families, where family and money relationships continue across national borders (Smart and Shipman, 2004). Pahl says that 'Assumptions about family finances developed in Europe and North America may not apply in other parts of the world' (Pahl, 2008, p. 558). She continues, 'We need to move from seeing the household as a bounded unit towards a view that stresses its permeability and its links with wider social and economic structures’ (pp. 586-587).

It is particularly important in Asia, the Pacific and Africa to recognise that the boundaries of domestic money can be broader than the couple and the nuclear household unit. In order to adequately study money within the household, it is important to study the money flows between the household and the wider family. A 1991 study of the Aboriginal Ngukurr community in south-east Arnhem Land (Senior et al., 2002) showed that money was distributed within the fluid household cluster rather than the household. Senior et al. said this cluster may 'vary in composition from a couple, 
nuclear family, extended family through to one based on a set of siblings or other close relatives' (p. 5). Gifts, mainly of money comprised an average of 16 per cent of the income of the household cluster.

To understand Maori money, it is also important to take into account the money that goes from households to the whānau, a group of kin descended from a common ancestor or an extended family group. Money is gifted up and down generations with younger people giving to 'parents, grandparents or others in their parent's generation as well as to brothers, sisters or cousins' (Taiapa, 1994). Money is gifted to the whānau for ritual gatherings to mark crises in the lives of whānau members. The obligation to gift money for the funeral meeting at the whânau takes priority over every day household expenses.

There is such a strong moral imperative to share money with extended kin and clan networks that migrants from many countries in Africa are subject to intense pressure. Somali refugees in London (Lindley, 2009) remit money not only to parents and siblings but also to 'uncles, aunts, in-laws, nephews, nieces, grandparents, cousins and others' (p. 1324). A study of Dinka migrants in the United States (Akuei, 2005) shows how a Dinka man is expected to contribute to bride price for three immediate generations on his father's side. He also has obligations to his wife's kin. Akuei, speaking of one of the participants, says 'Within the first two years of resettlement to San Diego, Joseph became directly responsible for 24 male and female extended family members and indirectly 62 persons displaced across a number of locations' (p. 7). Not meeting these obligations means that he is not a 'good moral person' (p. 4). In Fiji and Tonga, remittances also go to non-migrant households - nearly 20 and 80 per cent respectively (The World Bank, 2006). 


\section{The Indian joint family}

In this paper we focus on the Indian patrilineal joint family household as one example of the generational complexities of an extended family household and the broader boundaries of domestic money.

The most common form of the Indian joint family household is a three generation household marked by male descent. It comprises parents, sons and their children. It is this patrilineal joint family household which stands for the Indian family celebrated in popular culture (Uberoi, 2004: 297, Uberoi, 2006 , Uberoi, 1998).

The matrilineal joint family, marked by female descent, is more narrowly distributed in India among castes such as the Nayars in the south and the Khasis in the north-east. The tarawad among the Nayars is the most celebrated form of the traditional matrilineal joint family household (Patel, 2005). It used to have 20-30 members or more, owned property in common and consisted of 'all the matrilineal descendents of a common female ancestress' (pp 42-43). Women had greater rights and entitlements to property than in the patrilineal joint family, though it was the senior male, a woman's brother who controlled the affairs of the tarawad. The sister-brother tie was the central one, with the husband living in his own tarawad rather than with his wife. The importance of the tarawad has been declining as the bond between father and child gains more importance (Puthenkalam, 2005).

Joint family households have always been outnumbered by nuclear households, though it is likely that most people in India live in the bigger joint family households, particularly in rural areas and in North India (Uberoi, 2004). The joint family's importance is greater than its actual prevalence at any one point of time, for most individuals spend some part of their lives in a joint family household. Women most 
often start their married life in the patrilineal joint family household. When the joint family household disperses over time, it gives rise to various combinations of joint and/or nuclear family households. Ties of property and norms of joint family etiquette often remain (Shah, 2005 , Uberoi, 2004 , Das, 1976).

Sociological literature has confirmed the popular picture of the male control of money and property in the family. Money in the Indian family is studied with reference to women and paid work in middle-income households (Bhandari, 2005 , Ramu, 1989 , Sekaran, 1992 , Sharma, 1986 , Bhandari, 2004 , Indira Devi M., 1987); gifts and presentations related to life cycle events (Madan, 1993); the discussion of women and property (Basu, 2005b , Basu, 2005a , Kishwar, 2005 , Agarwal, 1994 , Panda and Agarwal, 2005 , Misra and Thukral, 2005 , Palriwala and Uberoi, 2005); and the impact of remittances on women’s money management roles in the household (Zachariah and Rajan, 2001 , Kurien, 2002).

In the following sections we describe how our qualitative study of money and information in Indian urban family households helped us recognise the wider importance of the familial context of money and generational complexity in joint family households. We then detail the implications of these dimensions for the analysis of the management and control of money. In the concluding section, we propose a broader cross-cultural typology to study money management and control in diverse forms of family across cultures.

\section{The qualitative study of money in the Indian family}

We conducted open-ended interviews between November 2007 and January 2008 in English, Hindi and Punjabi with 40 predominantly middle-income and upper middle income persons from 27 households. The interview sample includes 25 people living in 
metropolitan Delhi which in 2001 had a population of 12.9 million (Census of India Office of the Registrar General India, 2001), seven in a peri-urban area that is being developed into urban housing in the Delhi region, and eight people from Dharamshala, a small Himalayan town in India with some 20,000 people in 2001 (the latest data available). These three sites also broadened the study to include metropolitan, periurban and small town family households. We chose these three sites because both of us had personal, family and professional connections in these places, and so were confident we could have access to suitable participants. We did not interview members of our immediate family or close friends, but sought references from family, friends and colleagues to direct us to their networks. Their reference assured the participants about the nature of our study and allowed us access to examine the private nature of money in families. Having these connections with the participants meant that we did not ask about the quantum of money earned, spent or saved, but talked of broad ranges of household income, how information about money was shared, and how they perceived money was managed and controlled in their household.

The interviews ranged from 3.5 hours to just more than half an hour, usually conducted in the person's home. Most interviews lasted an hour to an hour and a half, with the formal interview flowing into a social visit. In 13 of the 27 households we interviewed more than one person - 12 married couples (husbands and wives separately for three couples), and in one household a mother-in-law and daughter-in-law. When husbands and wives were interviewed together we most likely got a different picture of household money, than if we had spoken to each of them individually. We also recognise we would have heard different representations of control and management if 
we had talked to all the adults in the household or had been able to observe the management and control of money in the household.

Our focus on representations of money management and control in the urban patrilineal joint family household in North India arose from an initial interest in the privacy of money in urban, middle-income family households. Hence our initial questions related to the way information about money was or was not shared across gender and generations, within the household and wider kin group. We asked about bank accounts and what happened to money earned by members of different generations in the household. These questions led to the family context of money and further probing of the generation and gender divide in information and access to money. Money and information flows within the two, three and four generation joint family households were particularly complex. In our study, 14 of our 40 participants lived in joint family households and 17 had experience of them.

\section{The participants}

The characteristics of our participants are set out in Table 1 . Thirty-five of the 40 people in our study defined themselves as upper middle, middle or lower middle. We used the National Council of Applied Economic Research's (NCAER) definition of the middle class in 2000-2001 as having an annual household income of between INR 2-10 lakhs

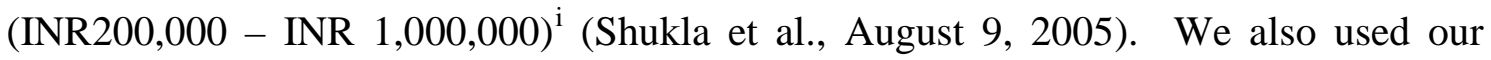
participants' perception of where they fit, using a mixture of income and the capacity to spend.

Table 1 here 
There are more women in our study, reflecting that as female researchers we had easier access to women. Men were often unavailable at the time of the interview. In two cases, the women said their husbands would be uncomfortable talking about money.

Our participants are predominantly from urban North India. It thus excludes the rural agrarian patrilineal joint family households and the matrilineal joint family households found in South and North-East India. This sample is not representative of Indian joint family households. However, the sample is diverse enough to cover varied dimensions of money management and control in the urban Indian patrilineal joint family.

\section{Coding and analysis in the grounded study}

This is a grounded study (Charmaz, 2000 , Strauss and Corbin, 1990), in that the emphasis is on a transparent fit between data and theory, rather than a testing of hypotheses. We recorded and selectively transcribed the interviews, noting aspects of the interview that were more like a social visit We used a computer program NVIVO 7 for the analysis of qualitative data. The use of the computer program involved a broad coding of data, analysing the coded data for the main themes, and transparently fitting the data to theory.

The program allowed us to identify not only what was said about money management and control, but even what was not said. It was in this process of coding the flow of information and money outside the household, in both nuclear and joint family households that we realised representations of money control at the household level needed to be distinguished from those pertinent to the couple and the individual. The focus had to be on generation as well as gender. Management of the household was 
also not unitary. Managing the kitchen did not necessarily translate to managing household or couple money.

\section{The family context of money}

People in our study speak of the importance of financial obligations to family. This is true for our metropolitan, peri-urban and small town participants. Money is shared between parents and adult children, and in some cases between siblings. This is a key family practice, irrespective of whether it is a nuclear or joint family household. This sense of filial obligation and mutual help is an important factor behind the estimated US\$55 billion in international remittances that flowed primarily to families in India in 2010 (Ratha et al., 2011).

A two-way flow of money between parents and children is central to family money. Parents acknowledge an obligation to help their adult children. Adult working children, particularly sons, including those not living at home, recognise an obligation to help their parents, even when their parents can do without. This obligation is couched in terms of 'duty' (dharma) on the children's part and a 'right' (haq) on the parents' part. In our study, there are five instances where a parent has a joint account with his or her adult children, making it easier for money to flow between parents and children. The two-way flow is accepted by parents and children. Our participants tell of money that is offered, rather than requested. In our study we have two cases of upper middle-income parents who have the ability and the wish to be financially independent, saying how their adult children keep offering them money.

The family context of money means information about money is shared beyond the couple and the household with wider kin. Unlike middle-income Anglo Celtic couples, information about money is not private to the marital couple (Singh, 1997). 
This family context may mean that information is shared across generation between father and son and between brothers. On the other hand, information about money may not be shared between husband and wife, leading to a greater gender divide in the management and control of money.

Urmila (all the names from the qualitative study are pseudonyms), 55, in a Dharamshala middle-income nuclear family household says she and her husband have substantially helped with building her parents-in-law's house. They have also helped with the marriages of her two sisters-in-law and a brother-in-law. Urmila is one of the few persons in our study who has not previously lived in a joint family household, as her husband had a transferable job. Deepak, in his early 30s, a high earning professional in Delhi, living in an upper middle-income joint family with an annual household income of more than INR30 lakhs, says, 'In my house, they expect me to give and I also want to give. ... We have to take care of our elders.' Deepak and his wife had recently taken money out of their savings to put towards another house his father bought. Deepak says, 'We bought the entire house together in Dad's name. He will give it back to me in a couple of years. It is all in the same family'.

The money also flows from parents to children as Jagdish's story shows. Jagdish, 74, retired from a senior government position, and now working as a consultant, says his father-in-law helped them with money for building their house. He later returned the money. His daughters do not give them money and Jagdish and his wife do not ask. But one daughter makes her car and driver available to them, and also paid INR 30,000 for Jagdish’s recent extra hospital expenses.

Mutual financial help between male and female siblings - on the husband and wife's sides - is shaped by relationships of reciprocity, need and capacity. It is usual to 
discuss money with kin from whom a person can expect help and advice. Ritu, 45, a school teacher in the Delhi metropolitan region relates how her brother and father helped substantially with money when Ritu and her husband were building their house. So she shares information about money with her brother and father. Money conversations do not take place with her husband's brothers, as they were neither asked nor did they offer to help with the house. Tara, in her early 50s, in Dharamshala also received help from her husband's brother and sister when Tara's husband had to be hospitalized. She says together ( $r a l$ mil kai), they were able to pay the INR 70,000 that was needed. This expense represented most of her household's annual income. Her husband's siblings and her sister helped with Tara's son's first year expenses for the engineering college.

The norms did not work out as expected in Santokh’s family and for Avinash and Asha. Santokh, 81, is from Dharamshala, with an annual household income of below INR 90,000. Loans to family members had not been returned and adult children continue to remain financially dependent on their parents. He therefore talks of money only with his wife and not with his children and their families.

Avinash and Asha's story is one where the family context of money led to intrigue, lost business and inheritance, adoption and return, brother against brother, and parents fearing the loss of home. Even as the wider family unravelled, Avinash, 62, and his wife Asha, 60, received money from their parents for their business, the building of their house and the wedding expenses of their daughters. Now that their daughters are married, Avinash and Asha watch whether their children are doing without, so that they can help. 


\section{Management and control of money in nuclear and joint family households}

In our study we linked money control with the power to make major financial decisions or prevent discussion about these decisions (Pahl, 1989 , Vogler, 1998 , Vogler and Pahl, 1993 , Vogler et al., 2008 , Lukes, 1974). Having information about money was a necessary condition for the control of money (Singh, 1997). We asked our participants about recent decisions about savings and investments. We also asked them how they saw the control of money in the household. Based on these factors, the households were seen to have male, female, joint or independent control.

We initially approached money management as organising money in the household on a day to day basis. We saw women as managing the money, if they had regular access to money either through the whole wage, housekeeping allowance or a banking account (Pahl, 1989). Access to money for personal expenditure was a key factor in women's representations of money management.

We then discovered that in the Indian family, there was another category - the 'irregular dole'. The irregular dole differs from the whole wage and the housekeeping allowance systems, in that money is given as a gift, rather than an entitlement. It is similar to what happened in the $19^{\text {th }}$ century in the United States (Zelizer, 1994). The woman has to ask for money and justify the need.

In our joint family households in peri-urban Delhi and Dharamshala, women have the keys to the kitchen. But the management of the kitchen does not translate to managing the money in the household or the couple, that is, organizing the routine grocery and household purchases, payment of bills and doing the banking. Women may have individual or joint bank accounts but they do not regularly conduct transactions or 
receive information from these accounts. Where women managed the kitchen only and had no regular access to money, we have classified it as male management. Women have least influence on money in the household when male control is combined with male management.

The generational dimension of control and management in the joint family household The generational dimension is important for probing the characteristics of money management and control in the joint family household. Money control and management at the household level may be follow the same pattern for the junior and senior couples, as happens in the joint family households with male control and male management. However, in our study, we also have two instances where the management and control of money for the joint family household is different from that followed by the junior couple. The junior couple contributes a part of their money towards household expenses. This means that the couple continues to be able to control a substantial part of their money. In one case, at the household and senior couple level, control is joint with female management. But with the junior couple, though the control is joint, money management is independent. In the second case, it is female control at the household and senior couple level, but the senior woman thinks her son and daughter-in-law control their money jointly.

We also have two cases where the widowed mother-in-law has her own income and controls and manages her own money, whereas the junior couple jointly or independently control their money and that of the household.

Being aware of the generational dimension of money management and control in joint family households ensures that variations within the household are taken into account. 


\section{$\underline{\text { Patterns of money control and management }}$}

Male control of money is the dominant pattern and found in about half the households we studied (see table 2). Joint control was found in a third of our households. Independent control and female control were of lesser importance with two and three households respectively. Female management was found in nearly three-fourths of our households. When accompanied by male control, it was predominantly the housekeeping allowance, with one household following the whole wage system. When found with joint, independent or female control women accessed money through separate or joint bank accounts.

Table 2 here

As noted above, we also found male management of money in our nonmetropolitan joint family households, ranging from the middle class to those that categorised themselves as 'struggling/deprived'. The women received money through the irregular dole. Male management was always accompanied by male control. There were no upper middle class households who had male control and male management of money. The incidence of male management of money among our households was greater than joint management, which was only found in three of the 27 households. 


\section{Male control and male management in non-metropolitan joint family households}

In the peri-urban and small town joint family households, male control is accompanied by male household management. Male control and management are found at both the levels of the household and the component couples. This pattern is different from Western studies of money which show that male control is often accompanied by female management via the whole wage management and the housekeeping allowance (Pahl, 1989).

Male control in our study has a greater spread across household income than in the West. It is found among the middle class, lower middle and the struggling households, rather than just in the lowest income group. Male management and control is not found among households that categorise themselves as upper middle class or global. Only one metropolitan upper middle class nuclear household has male control though accompanied by female management. The woman in this case, sees it as her choice, not wanting to know more about household money as it is complicated since her husband is in business with his father. They previously lived in a joint family household.

In joint family households with male control and male management, all or a major part of the money from the other members of the family is given to the male who is in control of the joint household's expenditure, savings and most of its investments. The male who does not control the household income, controls whatever money is left for the couple.

Women in joint family households with male control and male management have little information about money in the household or money that belongs to the couple. Information about money flows between the father and son or among brothers. Women also do not have assured access to money. Despite the mother-in-law being the 
archetypal figure representing power in the Indian patrilineal joint family household, our interviews show that in the non-metropolitan joint family households with male management and control, both the mother-in-law and daughter-in-law depend on the younger and/or older generation male for the 'irregular dole'. Both the mother-in-law and the daughter-in-law have minimal access to money or information as shown in the stories of Amar and Amrit and Rana and Rina below.

Amar is over 65 years old, and lives in Dharamshala with her son, daughter-inlaw and a grandson in a middle class household. Amar says when her husband was alive, he '...used to keep the money. He used to buy the rations. If I wanted to spend, I would ask for what was needed.’ Amar only discovered she and her husband had a joint account after he died. Now, her son looks after the money in their joint account.

Her daughter-in-law Amrit, a graduate in her late 40s or early 50s, says, The pattern is the same with me even in this generation ...I take from my husband what I need..... It is not that I get a certain amount every month. If I need to buy a shawl, I ask for money. If he says no, then there is no money.

Amrit says she knows about the major investment decisions in the household, such as the purchase of land, but only after the fact. Though she helps out occasionally in the family business, the information about business money is shared between the father and son. Amrit says,

He speaks with his son, not with me. I am also not interested in finding out. Even if I did take an interest, he will say, "It is not your concern. Why do you want to know? What will you get if you know?” 
Rina is similarly excluded from information about money. She is 24 , also a graduate, and lives with her husband Rana, 28, in a three generation household which includes her parents-in-law, Rana's younger brother and sister, and Rina and Rana's two sons - one and three years old. Rana controls the household income and is responsible for all the expenditure. His father gives his salary to Rana, according to the custom of his village, but keeps the tips from his government job and the revenue from land in the village, for himself and his ill wife. Rana's father manages and controls the money that is with him. Rana discusses his income and investments partially with his father but is not sure about his father's money.

The gender divide in information about money is impermeable. Rana does not talk of money with his mother or his wife. Rina does not have a bank account. She also does not ask him questions about money in his account. She says, 'If I ask, he would feel that I am trying to know his inner most secrets (dil ki baat). All I have to do is cook and feed the family.'

\section{Joint and independent control in metropolitan Delhi}

Joint and independent control is found mainly in upper middle class households in metropolitan Delhi. One of the 11 households is in the small town of Dharamshala. Only one of 11 households in this category sees itself as lower middle class. The women in 10 of the 11 households are graduates. In the joint family households this is true of women of both the senior and junior generations. The woman in the $11^{\text {th }}$ household has an advanced diploma.

The three instances of female control belonged to middle-class households. Of these three households, one woman was a single parent. The other two women were in 
salaried paid work, with the husband either not wanting to manage and control the money and/or recognising that the wife was more expert at it.

Most of the women in the households with joint or independent control - 8 of 11 - are in paid work. In households with joint control and joint management; and independent control, all the women are in highly paid jobs outside the home. The women have access to money through personal and/or joint bank accounts. Information is shared between the husband and wife. This picture is the one that is closest to that found among middle-income and affluent couples in the West (Pahl, 1989; Vogler, 2009).

\section{Analysing patterns of money management and control}

These patterns of money management and control are primarily explained by the same two factors that explain the 'allocative systems' of the West, but in different measure. As Vogler (2009) says, these systems

...are largely the result of two inter-related factors: first, the relative economic resources each partner contributes to the household (as measured by household employment status rather than income, because not all couples are economically active) and, secondly, cultural ideologies/discourses of gender, particularly those of male breadwinning versus newly emerging discourses of co-provisioning (pp 66-67).

In our study, the role of the ideology of male dominance looms large, and can lead to women not being permitted to work outside the home. This ideology of male dominance is central to male control across a broad spectrum of household income ranging from 'struggling' households to middle class households. This pattern goes 
against the pattern in the United Kingdom where male control and the whole wage system is found only with the lowest household income (Vogler, 2009).

The ideology of male dominance often prevents women earning an income outside the home. A woman's income contribution to the household becomes possible, not only with education, but also with an ideology that values women's work, and one where marriage is seen along the lines of a partnership. This is found mainly in metropolitan middle and upper middle class households with female, joint and independent control.

\section{Linking the ideology of male dominance and male control}

The ideology of male dominance expresses itself in the ownership of property; male dominance of the public sphere, particularly that of money; the man as the breadwinner with the woman looking after the family and home ((See (Basu, 2005b , Basu, 2005a , Kishwar, 2005 , Agarwal, 1994 , Panda and Agarwal, 2005 , Misra and Thukral, 2005 , Palriwala and Uberoi, 2005)). Being a good son and brother can take priority over being a good husband, particularly in the context of the joint family.

Unlike the pattern in the West (Pahl 1989), male control is not confined to the lowest income group. Among our households, the ideology of male dominance is most prevalent among the middle, lower middle and the 'struggling' households, particularly in non-metropolitan Delhi. Women with a bachelors' degree are prevented from going into paid work, for their primary role is to look after the family. Women in nuclear families may engage in small scale business activities at home, but even this is not permitted in the joint family households we studied. When male dominance is linked to male management, then a woman's access to money and information about money is minimal. 
An ideology of male control was important in 10 of the 13 households with male control. In three of the eight nuclear households, it was the women who said the husband knew more about money and handled it in the interests of the whole household. In the fourth - Jagdish and Jaya's household - Jagdish, 74, assumed that women were not interested in controlling money. The fifth case is that of Peu, 24, in a lower-middle class household in peri-urban Delhi who wants a career as a beautician. Her parents-inlaw told her 'our daughters-in-law have to observe purdah and cannot venture out on their own'. She says her husband does not object. For the present, Peu continues to be a housewife, saying her son is still too young. They are still linked financially with the parents-in-law as they have only recently separated from the joint family household,

The remaining three households differ as to the reasons for male control. In two households in Dharamshala, with an annual household income of less than INR 2 lakhs, there was little money to control. In the third household, Navin, 29, newly married, hopes that his wife Naina, 24 would begin to be independent with money once she finishes her law degree and gets familiar with metropolitan Delhi.

In the five joint family households, male control was accompanied by male management. The ideology of male dominance and the woman's place in the home is the common factor. None of the junior or senior women are in paid work, even if they have skilled qualifications and would like to be in paid work. Balbir and Bina's story below illustrates male control across generations and the role of ideology.

\section{Balbir and Bina's story}

Balbir, 28, and Bina, 23, live in a three generational patrilineal lower middle income joint family household in a peri-urban area near Delhi in a house that Balbir's 
grandfather built. Balbir and Bina have been married for a year and live with Balbir's parents, two sisters who are still going to university and two brothers still in school. Balbir continues to give all his monthly salary of INR 5,000- 6,000 to his father and then gets back from him some money for himself and his wife. He is also doing his MBA.

Balbir's father controls the household money and the money for himself and his wife. He makes all the decisions on major expenditure items. The father discusses them with Balbir, who is the eldest son, but the father has the major say. Both Balbir's mother and wife are excluded from these discussions. Money that is left over is placed inside a cupboard. The keys are with Balbir's mother. When Balbir wants some money for himself or his wife, his mother gives him the keys and he takes what he needs. Though Balbir's mother has the keys to the cupboard with the household money, each item of expenditure has to be approved by Balbir's father.

Balbir controls whatever money is given to him by his father. He discusses issues such as insurance, loans and investments with his father before deciding. When Bina wants money, she asks her husband.

Bina is a graduate and has done a six-month beautician's course. She say, 'I am a housewife nowadays but I want to work so that I leave home in the morning and return back by evening'. His parents are supportive and want her to get a teaching qualification and get a government job. But Balbir feels strongly that Bina should stay at home and look after his younger siblings first. Balbir's younger brother is studying to be an engineer. Balbir thinks his younger brother will not be as burdened by family responsibilities. Thinking of his younger brother’s marriage, he says, 'I would not bring a housewife for him’. 


\section{An ideology of partnership and women's paid work}

It is mainly in the upper middle class families that we heard stories of women's work being valued. Women were seen and saw themselves as partners in marriage and the household. Women in these families were highly educated and earned salaries that allowed them to manage their money independently if they so chose. The ideology of the partnership of marriage does not focus solely on the togetherness of the couple, but is placed within the context of a harmonious extended family.

In the West, the move is from an ideology of marriage as an equal partnership, to the growing importance of independence in relationships. Unlike the discussions about equality and equity; partnership and individuation among couples in the West (Nyman, 2003; Pahl, 2008; Vogler, 2009), in our study we heard more about the couple's place in the wider family. This is true of nuclear and joint family households. It is important to remember that 11 of the 18 nuclear households we studied used to be part of joint family households. The conversations then are of managing and controlling money so that the couple can help parents on the one hand and adult children on the other.

The story of Deepak's family is very different from that of Amar and Amri, illustrating the difference between the ideology of male dominance and partnership. Deepak is in his early 30s and works with a multinational company. He belongs to a two generation upper middle class joint family household. When Deepak began working, he used to give his whole salary to his mother. He got married seven months ago. He and 
his wife, who is in financial services, jointly control their money, while his parents jointly control the money of the household.

Deepak and his wife have separate accounts where their individual salaries are deposited. Neither controls the other's personal spending. The separate accounts earmark separate salaries for taxation purposes. They also have a joint account where they are saving for a future home and children. Deepak and his wife discuss their future, in the context of the joint family’s welfare. As noted above, they jointly decided to contribute to the house that Deepak's father was buying. They also openly discuss the amount of money they need to contribute for the running of the household.

Deepak’s story is replicated in Preeta’s story below, where Preeta and her husband jointly control their money and Preeta manages the household that includes her mother-in-law.

\section{Generational change in the management and control of money}

People often describe their present money management and control in the context of generational change. People in the 11 nuclear households that were previously joint usually begin their story with money management and control in the joint family. Though some joint families have continued with the tradition of male control and male management, in some joint families, this pattern has changed over the generation to one of joint control and female management of the joint family household. This is illustrated in Preeta’s story below.

\section{Preeta's story}


Preeta, in her late 40s or early 50s, is part of an upper middle-class three-generational joint family with an annual household income of over INR 30 lakhs. She is married to the only son of the family. Her mother-in-law lives on the first floor. Preeta, her husband and their two boys, still in school, live on the ground floor. They have all their meals together on the first floor.

Preeta and her husband jointly control the money for the household and for themselves. Preeta manages the money for the household, and manages the couple's money. Preeta's mother-in-law controls and manages her own money. Preeta's management role has emerged over time as her mother-in-law has withdrawn from the role because of old age, illness and the death of her husband.

When Preeta's mother-in-law (a graduate) got married, her husband, a professional would give most of his money to his mother. He gave his wife a small amount when he wanted to. If she wanted anything above that amount 'she had to go to her mother-in-law and ask her. Then the mother-in-law would give her money if she was in a mood to.' It was only after Preeta's mother-in-law died that Preeta's father-inlaw began giving his wife the money he earned. But even then, he discussed his investments with his son, but not with his wife. Preeta's father-in-law and mother-inlaw had a joint bank account, but the family only discovered it after the father-in-law's death. However, her mother-in-law at that stage was placing money in fixed deposits for herself or together with her daughters.

Preeta says her father-in-law felt 'it was very important to be a good son. He forgot it was important to be a good husband as well.' Unlike her mother-in-law, Preeta has had no problem with personal spending money. Preeta’s husband gave Preeta the money to give to his mother. Preeta has access to and transacts via the joint account she 
and her husband have together. She says she knows 'absolutely what my husband has.' She keeps herself well informed so that she can be part of the decision making about money. The key to this generational change is neither income nor education, for both Preeta and her mother-in-law had a BA degree and were part of high-income households. Preeta says the shift happened because her husband thinks it is equally important to be a good son and a good husband.

\section{Conclusion}

Our study of money in urban Indian middle-income patrilineal households has added two additional ways of examining money management and control - the family context and the generational dimensions of money. These two factors are important for the cross-cultural study of families and particularly for extended family households.

The family context of money recognizes that across cultures, the couple is not necessarily the central domestic financial unit marking the boundaries of domestic money. The family context of money means there is a two-way flow of money between parents, children and wider kin. This family context of money was true of our nuclear and the joint family households in metropolitan Delhi, peri-urban Delhi and Dharamshala. The generational dimension of money is essential for understanding the complexity of money management and control in joint family households. In a joint family household, it is important to examine the different layers of money management and control by focusing on money management and control at the level of the household and of the component couples.

Men controlled the money in nearly half the households we studied. In our joint family households in peri urban Delhi and Dharamshala, male control was accompanied by male management where the woman received money by 'irregular dole'. The male 
control of money was found in households with the ideology of male dominance with the woman's place being in the home. This ideology was found across a broad spectrum of household income and actively prevented educated women from paid work.

Patterns of joint and independent money control and management were found in a smaller proportion of our households. This pattern is most often found in higher income households where the women are in paid work and earn an independent income. It mimics the demographics for independent management and control in the West. The difference is that the ideology behind a couple's joint control and management of their money is the welfare of the wider family, rather than only signifying the couple's togetherness, independence and/or equality.

A broader framework of money that includes the family and the generational context of money, will help us understand the control and management of money across cultures. It will also connect the literature on money management and control with that on the transnational family, where money flows across generations and borders. Once the frameworks are in place, it will be possible to undertake generalisable studies of the management and control of money in Asia, the Pacific and Africa. We will then be able to examine patterns of money management and control against the role of ideology, household income, women's education, paid work, active bank accounts, and information about household money. We may find that the meanings of jointness and separateness in relationships are different within and between cultures. These studies will help us understand the relative influence and demographic spread of ideologies and world views, thus placing Western literature in a more global context.

\section{References}


AGARWAL, B., (1994). A Field of One's Own: Gender and Land Rights in South Asia, Cambridge, Cambridge University Press.

AKUEI, S. R. (2005). Remittances as unforeseen burdens:t e livelihoods and social obligations of Sudanese refugees. Global Migration Perspectives. Geneva: Global Commission on International Migration.

BASU, S. 2005a. Haklenewali: Indian Women's Negotiations of Discourses of Inheritance. In: BASU, S. (ed.) Dowry \& Inheritance. New Delhi: Women Unlimited.

BASU, S. 2005b. The Politics of Giving: Dowry and Inheritance as Feminist Issues. In: BASU, S. (ed.) Dowry \& Inheritance. New Delhi: Women Unlimited.

BHANDARI, M., (2004). Quality of Life of Urban Working Women Delhi, Abhijeet Publishers.

BHANDARI, M. (2005). The globalized woman in urban India: A case study. Delhi.

BURGOYNE, C. (2004). Heart-Strings and Purse-Strings: Money in Heterosexual Marriage. Feminism \& Psychology, 14, 165-172.

BURGOYNE, C. \& SONNENBERG, S. 2009. Heterosexual Couples A Perspective from Economic Psychology In: MILES, J. \& PROBERT, R. (eds.) Sharing Lives, Dividing Assets : An Inter-Disciplinary Study. Oxford and Portland, Oregon: Hart Publishing.

BURGOYNE, C. B. \& MORISON, V. (1997). Money in remarriage: keeping things simple - and separate. The Sociological Review, 363-395.

CENSUS OF INDIA OFFICE OF THE REGISTRAR GENERAL INDIA. (2001). Census of India 2001 [Online]. New Delhi. Available: http://www.censusindia.gov.in [Accessed 20 May 2008].

CHARMAZ, C. 2000. Grounded theory: Objectivist and Constructivist Methods. In: DENZIN, N. K. \& LINCOLN, Y. S. (eds.) Handbook of Qualitative Research. Second ed. London: Sage Publications.

DAS, V. (1976). Masks and faces: An essay on Punjabi kinship. Contributions to Indian sociology, 10, 1-30.

ELIZABETH, V. (2001). Managing money, managing coupledom: a critical examination of cohabitants' money management practices. The Sociological Review, 389-411.

INDIRA DEVI M., (1987). Women, Education, Employment, Family, Living: A Study of Emerging Hindu Wives in Urban India New Delhi, Gian Publishing.

KISHWAR, M. 2005. Dowry and inheritance rights. In: BASU, S. (ed.) Dowry \& Inheritance. New Delhi: Women Unlimited.

KURIEN, P. A., (2002). Kaleidoscopic Ethnicity: International Migration and the Reconstruction of Community Identities in India, New Delhi, Oxford University Press.

LINDLEY, A. (2009). The Early-Morning Phonecall: Remittances from a Refugee Diaspora Perspective. Journal of Ethnic and Migration Studies, 35, 1315 - 1334.

LOWN, J. M. \& DOLAN, E. M. (1988). Financial challenges in remarriage. Lifestyle: Family and Economic Issues, 9, 73-88.

LUKES, S., (1974). Power: A Radical View, London, Macmillan.

MADAN, T. N. 1993. Structural implications of marriage alliance in North India: Wifegivers and wife-takers among the Pandits of Kashmir. In: UBEROI, P. (ed.) Family, Kinship and Marriage in India. Delhi: Oxford University Press. 
MISRA, S. \& THUKRAL, E. G. 2005. A study of two villages in Bihar. In: BASU, S. (ed.) Dowry \& Inheritance. New Delhi: Women Unlimited.

NYMAN, C. (2003). The social nature of money: Meanings of Money in Swedish Families. Women's Studies International Forum, 26, 79-94.

NYMAN, C. \& REINIKAINEN, L. 2007. Elusive independence in a context of gender equality in Sweden. In: STOCKS, J., DÍAZ, C. \& HALLERÖD, B. (eds.) Modern Couples Sharing Money, Sharing Life. Basingstoke, Hampshire: Palgrave Macmillan.

PAHL, J., (1989). Money and marriage, London, Macmillan.

PAHL, J. (2008). Family finances, individualisation, spending patterns and access to credit Journal of Socio-Economics, 37, 577-591.

PALRIWALA, R. \& UBEROI, P. (2005). Marriage and Migration in Asia: Gender Issues. Indian Journal of Gender Studies, 12, v-xxix.

PANDA, P. \& AGARWAL, B. (2005). Marital violence, human development and women's property status in India. World Development, 33, 823 - 850.

PATEL, T. 2005. Introduction. In: PATEL, T. (ed.) The Family in India: Structure and Practice. New Delhi: Sage.

PUTHENKALAM, S. J. 2005. The family organization in the south-west of India. In: PATEL, T. (ed.) The Family in India: Structure and Practice. New Delhi: Sage.

RAMU, G. N., (1989). Women, Work and Marriage in Urban India, New Delhi, Sage Publications.

RATHA, D., MOHAPATRA, S. \& SILWAL, A. (2011). Prospects - Migration and Remittances Factbook 2011 [Online]. Washington D.C.: Development Prospects Group at the World Bank. Available: http://econ.worldbank.org/WBSITE/EXTERNAL/EXTDEC/EXTDECPROSPE CTS/0,,contentMDK:21352016 pagePK:64165401 piPK:64165026 theSitePK: 476883 isCURL:Y,00.html [Accessed 19 May 2011].

SEKARAN, U. 1992. Middle-Class Dual-Earner Families and their Support Systems in urban India. In: LEWIS, S., IZRAELI, D. N. \& HOOTSMANS, H. (eds.) DualEarner Families: International Perspectives. London: Sage Publications.

SENIOR, K., PERKINS, D. \& BERN, J. (2002). Variation in material wellbeing in a welfare based economy. Wollongong: South East Arnhem Land Collaborative Research Project, University of Wollongong.

SHAH, A. M. 2005. The phase of dispersal in the Indian family process. In: PATEL, T. (ed.) The Family in India: Structure and Practice. New Delhi: Sage.

SHARMA, U., (1986). Women's Work, Class and the Urban Household, London, Tavistock Publications Ltd.

SHUKLA, R. K., DWIVEDI, S. K. \& SHARMA, A. (August 9, 2005). The Great Indian Market: :Results from the NCAER's Market Information Survey of Households [Online]. National Council for Applied Economic Research. Available: http://www.ncaer.org/downloads/PPT/TheGreatIndianMarket.pdf [Accessed 25 September 2007].

SINGH, S., (1997). Marriage Money: The Social Shaping of Money in Marriage and Banking, St. Leonards, NSW, Allen \& Unwin.

SINGH, S. \& LINDSAY, J. (1996). Money in heterosexual relationships. Australian and New Zealand Journal of Sociology, 32, 57-69.

SMART, C. \& SHIPMAN, B. (2004). Visions in monochrome: families, marriage and the individualization thesis. The British Journal of Sociology, 55, 491-509. 
STRAUSS, A. \& CORBIN, J., (1990). Basics of qualitative research: Grounded theory procedures and techniques, Newbury Park, Calif., Sage Publications.

TAIAPA, J. T. T. (1994). "Ta Te Whanau Ohanga": The economics of the whanau The Maori component of the Intra Family Income Study. Palmerston North: Department of Maori Studies, Massey University.

THE WORLD BANK, (2006). At Home and Away: Expanding Job Opportunities for Pacific Islanders Through Labor Mobility

Washington D.C, The World Bank.

UBEROI, P. (1998). The diaspora comes home: Disciplining desire in DDLJ. Contributions to Indian sociology, 33, 305-334.

UBEROI, P. 2004. The family in India. In: DAS, V. (ed.) Handbook of Indian Sociology. New Delhi: Oxford.

UBEROI, P., (2006). Freedom and Destiny: Gender, Family, and Popular Culture in India, New Delhi, Oxford University Press.

VOGLER, C. (1998). Money in the household: some underlying issues of power. The Sociological Review, 46, 687-713.

VOGLER, C. (2005). Cohabiting couples: retinking money in the household at the beginning of the twenty first century. The Sociological Review, 1-29.

VOGLER, C. 2009. Managing Money in Intimate Relationships: Similarities and Differences between Cohabiting and Married Couples. In: MILES, J. \& PROBERT, R. (eds.) Sharing Lives, Dividing Assets : An Inter-Disciplinary Study. Oxford and Portland, Oregon: Hart Publishing.

VOGLER, C., LYONETTE, C. \& WIGGINS, R. D. (2008). Money, power and spending decisions in intimate relationships. The Sociological Review, 56, 117143.

VOGLER, C. \& PAHL, J. (1993). Social and economic change and the organisation of money within marriage. Work, Employment and Society, 7, 71-95.

ZACHARIAH, K. C. \& RAJAN, S. I. (2001). Gender Dimensions of Migration in Kerala: Macro and Micro Evidence. Asia-Pacific Population Journal, September 2001, 16, 47-70.

ZELIZER, V., (1994). The Social Meaning of Money, New York, Basic Books. 
Table I: Characteristics of the participants $(n=40)$

\begin{tabular}{|c|c|c|}
\hline Characteristics & $\begin{array}{l}\text { Number of participants } \\
\mathrm{N}=40\end{array}$ & $\begin{array}{l}\text { Number of households } \\
\mathrm{N}=27\end{array}$ \\
\hline \multicolumn{3}{|l|}{ Gender } \\
\hline Male & 16 & \\
\hline Female & 24 & \\
\hline \multicolumn{3}{|l|}{ Location } \\
\hline Metropolitan Delhi & 25 & 17 \\
\hline Peri-urban Delhi & 7 & 4 \\
\hline Dharamshala & 8 & 6 \\
\hline \multicolumn{3}{|l|}{ Age range } \\
\hline $18-24$ years & 3 & \\
\hline $25-34$ & 7 & \\
\hline $35-44$ & 8 & \\
\hline $45-54$ & 8 & \\
\hline $55-64$ & 7 & \\
\hline $65+$ & 6 & \\
\hline Did not ask & 1 & \\
\hline \multicolumn{3}{|l|}{ Annual household income } \\
\hline Below INR 90,000 & 2 & \\
\hline INR 90,000-INR 1.99 lakhs & 2 & \\
\hline INR 2 lakhs - INR 4.99 lakhs & 7 & \\
\hline INR 5 lakhs - INR 9.99 lakhs & 10 & \\
\hline INR 10 lakhs - INR 14.99 lakhs & 1 & \\
\hline More than INR 15 lakhs & 6 & \\
\hline Did not know & 3 & \\
\hline Did not want to say & 4 & \\
\hline Did not ask & 5 & \\
\hline \multicolumn{3}{|l|}{ Perceived income group } \\
\hline Upper middle/global & 12 & 11 \\
\hline Middle & 17 & 8 \\
\hline Lower middle & 6 & 4 \\
\hline Struggling/deprived & 4 & 3 \\
\hline Did not want to say & 1 & 1 \\
\hline \multicolumn{3}{|l|}{$\begin{array}{l}\text { Highest completed educational } \\
\text { level }\end{array}$} \\
\hline Bachelor degree or above & 26 & \\
\hline Diploma or advanced diploma & 3 & \\
\hline Secondary education & 9 & \\
\hline Primary school & 2 & \\
\hline \multicolumn{3}{|l|}{ Kind of households } \\
\hline Nuclear & 26 & 18 \\
\hline Joint family & 14 & 9 \\
\hline 2 generation & 5 & 3 \\
\hline 3 generation & 7 & 5 \\
\hline 4 generation & 2 & 1 \\
\hline
\end{tabular}




\begin{tabular}{|c|l|l|}
\hline Characteristics & $\begin{array}{l}\text { Number of participants } \\
\mathrm{N}=40\end{array}$ & $\begin{array}{l}\text { Number of households } \\
\mathrm{N}=27\end{array}$ \\
\hline $\begin{array}{l}\text { People in nuclear households with } \\
\text { joint family experience }\end{array}$ & & 11 \\
\hline Yes & 17 & 7 \\
\hline No & 9 & \\
\hline
\end{tabular}


Table 2: Socio-economic characteristics, money management and control in nuclear and joint family households $(\mathrm{n}=27)$

\begin{tabular}{|c|c|c|c|c|c|c|c|c|c|c|}
\hline \multirow{2}{*}{$\begin{array}{l}\text { Money } \\
\text { management } \\
\text { and control }\end{array}$} & \multicolumn{5}{|c|}{ Nuclear family households } & \multicolumn{5}{|c|}{ Joint family households (at the household level) } \\
\hline & No. & $\begin{array}{l}\text { Women's } \\
\text { education } \\
\text { BA and } \\
\text { above }\end{array}$ & $\begin{array}{l}\text { Women } \\
\text { in paid } \\
\text { work }\end{array}$ & $\begin{array}{l}\text { Metropo- } \\
\text { litan }\end{array}$ & $\begin{array}{l}\text { Upper } \\
\text { middle/ } \\
\text { global }\end{array}$ & $\begin{array}{l}\text { No } \\
\text {. }\end{array}$ & $\begin{array}{l}\text { Women's } \\
\text { education } \\
\text { BA and } \\
\text { above }\end{array}$ & $\begin{array}{l}\text { Women } \\
\text { in paid } \\
\text { work }\end{array}$ & $\begin{array}{l}\text { Metropo- } \\
\text { litan }\end{array}$ & $\begin{array}{l}\text { Upper } \\
\text { middle } \\
\text { /global }\end{array}$ \\
\hline $\begin{array}{l}\text { Male control } \\
\text { and female } \\
\text { management }\end{array}$ & 8 & 3 & $5 * *$ & 5 & 1 & Nil & & & & \\
\hline $\begin{array}{l}\text { Male control } \\
\text { and male } \\
\text { management }\end{array}$ & Nil & & & & & 5 & 3 & Nil & Nil & Nil \\
\hline $\begin{array}{l}\text { Joint control and } \\
\text { female } \\
\text { management }\end{array}$ & 5 & 4 & $4 * * *$ & 4 & 4 & 2 & 2 & Nil & 2 & 2 \\
\hline $\begin{array}{l}\text { Joint control and } \\
\text { joint } \\
\text { management }\end{array}$ & 2 & 2 & 2 & 1 & 2 & Nil & & & & \\
\hline $\begin{array}{l}\text { Female control } \\
\text { and female } \\
\text { management }\end{array}$ & $2 *$ & 2 & 1 & 2 & Nil & 1 & 1 & 1 & 1 & nil \\
\hline
\end{tabular}




\begin{tabular}{|c|c|c|c|c|c|c|c|c|c|c|}
\hline \multirow{2}{*}{$\begin{array}{l}\text { Money } \\
\text { management } \\
\text { and control }\end{array}$} & \multicolumn{5}{|c|}{ Nuclear family households } & \multicolumn{5}{|c|}{ Joint family households (at the household level) } \\
\hline & No. & $\begin{array}{l}\text { Women's } \\
\text { education } \\
\text { BA and } \\
\text { above }\end{array}$ & $\begin{array}{l}\text { Women } \\
\text { in paid } \\
\text { work }\end{array}$ & $\begin{array}{l}\text { Metropo- } \\
\text { litan }\end{array}$ & $\begin{array}{l}\text { Upper } \\
\text { middle/ } \\
\text { global }\end{array}$ & $\begin{array}{l}\text { No } \\
\text {. }\end{array}$ & $\begin{array}{l}\text { Women's } \\
\text { education } \\
\text { BA and } \\
\text { above }\end{array}$ & $\begin{array}{l}\text { Women } \\
\text { in paid } \\
\text { work }\end{array}$ & $\begin{array}{l}\text { Metropo- } \\
\text { litan }\end{array}$ & $\begin{array}{l}\text { Upper } \\
\text { middle } \\
\text { /global }\end{array}$ \\
\hline $\begin{array}{l}\text { Independent } \\
\text { control and } \\
\text { female } \\
\text { management }\end{array}$ & 1 & 1 & 1 & 1 & 1 & nil & & & & \\
\hline $\begin{array}{l}\text { Independent } \\
\text { control and joint } \\
\text { management }\end{array}$ & & & & & & 1 & 1 & 1 & 1 & 1 \\
\hline Total & 18 & 12 & 13 & 13 & 8 & 9 & 7 & 2 & 4 & 3 \\
\hline
\end{tabular}

*Includes one single parent household.

**All the women are in family business or home based business, where the husband is the main earner

*** Two of these four women are in home-based business where the husband is the main earner. The other two have businesses outside the home. 
${ }^{\mathrm{i}}$ On 15 April 2008 (close to the timing of the study), INR 100 equalled US\$ 2.50305 and $£ 1.27022$. One lakh equals INR 100,000. So INR 100,000 equalled US\$2,503 and £1,270. On 28 June 2011, INR 100,000 equalled US\$2,220.30 and $£ 1,392.31$. 